\title{
Efficacy of potassium permanganate and turmeric as antimicrobial agents on the bacterial load and quality of boar semen during preservation at $15^{\circ} \mathrm{C}$
}

\author{
Nang Kanna Manpoong ${ }^{1}$, Kutubuddin Ahmed ${ }^{1}$, Dilip Kumar Bhattacharya ${ }^{2}$, \\ Dipak Kumar Sarma ${ }^{1}$, Nekibuddin Ahmed ${ }^{3 *}$, and Arunoday Das ${ }^{3}$ \\ ${ }^{1}$ Department of Animal Reproduction, Gynaecology and Obstetrics, College of Veterinary Science, Assam \\ Agricultural University, Guwahati, Assam, India \\ ${ }^{2}$ Department of Veterinary Microbiology, College of Veterinary Science, Assam Agricultural University, Guwahati, \\ Assam, India \\ ${ }^{3}$ Department of Animal Reproduction, Gynaecology and Obstetrics, Lakhimpur College of Veterinary Science, \\ Assam Agricultural University, Lakhimpur, Assam, India
}

MANPOONG, N. K., K. AHMED, D. K. BHATTACHARYA, D. K. SARMA, N. AHMED, A. DAS: Efficacy of potassium permanganate and turmeric as antimicrobial agents on the bacterial load and quality of boar semen during preservation at $15^{\circ} \mathrm{C}$. Vet. arhiv 90, 443-451, 2020.

\section{ABSTRACT}

The present study was conducted to evaluate the efficacy of different natural antimicrobials agents $\left(\mathrm{KMnO}_{4}\right.$ and Turmeric) in comparison with conventional antibiotics against the bacterial load and in relation to the quality of boar semen in Modena extender for up to 120 hours of preservation at $15^{\circ} \mathrm{C}$. A total of 56 ejaculates, 14 from each of four Hampshire crossbred boars maintained within the ICAR-AICRP on Pigs, in Guwahati, Assam, India, were utilized in the study. Thirty-two ejaculates, 8 from each of four boars were used to study the effect of antimicrobial agents on semen quality during preservation at $15^{\circ} \mathrm{C}$ in Modena extender. A total of 9 different bacterial types were identified from 46 bacterial isolates, obtained from 24 fresh semen samples viz. Staphylococcus aureus (24\%), E. coli (22\%), Bacillus spp. (13\%), Citrobacter spp. (9\%), Pseudomonas spp. (9\%), Staphylococcus epidermidis (9\%), Klebsiella spp. (6\%), Streptococcus spp. (6\%) and Proteus spp. (2\%). The overall sensitivity of the recovered isolates to Gentamicin, Ampicillin, Enrofloxacin, Cloxacillin, Streptomycin, Penicillin, Amoxycilln, Ofloxacin and Tetracyclin were 89, 39, $37,48,74,52,56,76$ and $63 \%$ respectively. The mean sperm motility, intact acrosome, HOST-reacted spermatozoa and bacterial load differed significantly $(\mathrm{P}<0.01)$ between antimicrobial agents (Gentamicin, $\mathrm{KMnO}_{4}$ and $\left.\mathrm{Turmeric}\right)$ and preservation periods $(0,48,72,96$ and 120 hours). Sperm quality based on Gentamicin was found to be best, followed by Turmeric and $\mathrm{KMnO}_{4}$ during preservation at $15^{\circ} \mathrm{C}$. The conception rate for the semen preserved for 0,24 , $48,72,96$ and 120 hours of preservation was 83.33, 80.00, 75.00, 66.66, 66.66 and 50.00\% respectively. In the present study, the preserved semen with ascending bacterial load containing Gentamicin did not affect the conception rate.

Key words: antimicrobials; bacterial load; semen quality; preservation; conception

\footnotetext{
*Corresponding author:

Assist. Prof. Nekibuddin Ahmed, Department of Animal Reproduction, Gynaecology and Obstetrics, Lakhimpur College of Veterinary Science, Assam Agricultural University, Assam, India, E-mail: nekibahmeds@gmail.com
} 


\section{Introduction}

Boar semen harbours a broad range of microorganisms, despite the application of strict hygienic measures during collection and semen processing. In the swine industry, this bacterial contamination is very serious and a real obstacle to a successful artificial insemination (AI) programme. Normally, boar ejaculates contain $10^{3}$ to $10^{5}$ colony forming units (ALTHOUSE and LU, 2005; MORRELL and WALLGREN, 2011), although bacterial contamination can reach concentrations up to $10^{9}$ $\mathrm{cfu} / \mathrm{mL}$ (ALTHOUSE et al., 2000).

The effects of different types of bacterial contamination on the quality of boar sperm are manifold, viz. abnormal sperm motility and impairment of membrane integrity (UBEDA et al., 2013; FRACZEK and KURPINZ, 2015), ultra structural morphological alterations and degenerative acrosome exocytosis (KOHN et al., 1998; PRIETO-MARTINEZ et al., 2014), mitochondrial activity diminution (FRACZEK et al., 2012), an increase in DNA fragmentation (FRACZEK et al., 2015), and sperm agglutination (UBEDA et al., 2013).

As a preventive measure for bacterial contamination, antibiotics are added to the semen extender. Several studies have opined that a large number of bacteria frequently isolated from boar ejaculates are currently resistant to the most common antibiotics added to semen extenders (YANIZ et al., 2010; MORRELL and WALLGREN, 2011). The ineffectiveness of preventive antibiotics in controlling bacteria in semen leads to the fact that the extender composition becomes a potential medium for bacterial growth even at low temperatures (ALTHOUSE et al., 2000). The lower temperature used to reduce metabolic activity and to induce dormancy in sperm cells, in order to prolong their longevity, can also favour the growth of bacteria as they can adapt to temperature change (ALTHOUSE et al., 2008).

Traditional reliance on antibiotics has been weakened by the increasing appearance of antibiotic resistant bacteria in semen. Hence, there is an urgent need to find alternatives to conventional antibiotics for use in semen extenders.
Hence, the aim of this study was to investigate the bacterial load in boar semen, the antibiotic sensitivity of various bacteria isolated from boar semen and the effect of different antimicrobial agents in comparison with conventional antibiotics on the quality of boar semen in Modena extender for up to 120 hours of preservation at $15^{\circ} \mathrm{C}$.

\section{Materials and methods}

Animal. Four clinically healthy crossbred breeding Hampshire boars maintained within the Indian Council of Agricultural Research (ICAR)All India Coordinated Research Project (AICRP) on Pigs, College of Veterinary Science, Guwahati, Assam, India, were used for semen collection. The animals were maintained under a standard feeding regimen and management practices.

Semen collection. A total of 56 semen samples, 14 from each of four boars, were collected once weekly from each boar by the gloved hand technique (SHIPLEY, 1999) using a fixed iron dummy as mount. Out of 56 samples, 24 (six from each of four boars) were used for determination of bacterial load and the antibiotic sensitivity of bacteria in freshly collected boar semen.

Isolation and identification of bacteria. Each isolate was studied with respect to colony character and reaction to Gram's stain. The isolates were further identified on the basis of the list of characters mentioned in Bergey's manual of determinative bacteriology (BUCHANAN and GIBBONS, 1974).

Antibiotic sensitivity. Antibiotic sensitivity was tested by using 9 antibiotic discs (HI-MEDIA Co. Mumbai, India) viz. Ampicillin (10 mcg), Cloxacillin (10 mcg), Gentamicin (10 mcg), Streptomycin (10 $\mathrm{mcg}$ ), Penicillin (10 unit), Enrofloxacin (5 mcg), Amoxycillin (30 mcg), Ofloxacin $(5 \mathrm{mcg})$ and Tetracycline ( $30 \mathrm{mcg}$ ) by the disc diffusion method, as described by CRUICKSHANK et al., (1975).

Preservation of semen. A total of 32 ejaculates, comprising 8 from each of 4 boars, were used for evaluation of the effect of antimicrobial agents on the quality of boar semen, during preservation at $15^{\circ} \mathrm{C}$. Immediately after semen collection, each ejaculate was evaluated for volume, mass motility (based on the 0-4 numeric scale of ZEMJANIS, 1970, 
and initial sperm motility. Only ejaculates with a minimum volume of $190 \mathrm{~mL}, 3+$ mass activity and $80 \%$ initial sperm motility were used for the study. The strained volume of semen was kept for holding at $22{ }^{\circ} \mathrm{C}$ for 4 hours. Each semen ejaculate was split after holding into three fractions and extended (1:4) with Modena extender. Then, each part was treated with the most sensitive antibiotic (Gentamicin), potassium permanganate $\left(\mathrm{KMnO}_{4}\right)$ and Turmeric (Table 1). The samples were then preserved in glass beakers, sealed with aluminium foil, at $15{ }^{\circ} \mathrm{C}$ in a BOD incubator for up to 120 hours.

Table 1. Composition of Modena extender (Sone et al., 1992)

\begin{tabular}{|l|c|}
\hline Glucose & $2.75 \mathrm{~g}$ \\
\hline Sodium citrate & $0.69 \mathrm{~g}$ \\
\hline Sodium bicarbonate & $0.10 \mathrm{~g}$ \\
\hline EDTA Sodium salt & $0.235 \mathrm{~g}$ \\
\hline Citric acid & $0.29 \mathrm{~g}$ \\
\hline Tris & $0.525 \mathrm{~g}$ \\
\hline $\begin{array}{l}\text { De-ionized triple glass } \\
\text { distilled water up to }\end{array}$ & $100 \mathrm{~mL}$ \\
\hline $\mathrm{pH}$ & 6.9 \\
\hline
\end{tabular}

Extender with antimicrobial agents

Modena extender with Gentamicin sulphate @ $150 \mu \mathrm{g} / \mathrm{mL}$ of extender Gentamicin sulphate $\quad 0.3 \mathrm{~mL}$ Modena extender $\quad 99.7 \mathrm{~mL}$

Modena extender with $\mathrm{KMnO}_{4} @ 10 \mu \mathrm{M}$ (freshly prepared) $\mathrm{KMnO}_{4} \quad 10 \mu \mathrm{M}$ Modena extender $\quad 100 \mathrm{~mL}$

Modena extender with Turmeric@0.5 mM

Turmeric $\quad 0.5 \mathrm{mM}$

Modena extender $\quad 100 \mathrm{~mL}$

Evaluation of preserved semen. The preserved semen was kept at $37^{\circ} \mathrm{C}$ for two minutes and gently shaken for homogenization prior to evaluation. The evaluation for sperm motility, intact acrosome, Hypo osmotic sperm test(HOST)-reacted sperm and bacterial load at 0 (immediately after extension), 48, 72, 96 and 120 hours of preservation were carried out as per the standard methods described by early researchers (BLOM, 1950; REVEL and MRODE, 1994).

Artificial insemination (AI) trial. A total of forty-seven sows between their second and fourth parities, maintained within the ICAR-AICRP on Pigs, and in and around Guwahati, Assam, India, by private breeders were utilized for AI. Semen extended (1:4) in the Modena extender, containing the best antimicrobial agent (Gentamicin) was packed in GTB bags (IMV Technologies, L'Aigle cedex, France) keeping $80 \mathrm{~mL}$ per dose. For $\mathrm{AI}$, the same preserved semen was held at $15{ }^{\circ} \mathrm{C}$ in a BOD incubator used for up to 120 hours of preservation with simultaneous semen evaluation. Oestrus was detected on the basis of behavioural and physical alterations, however it was confirmed by the presence of the stance reflex. Artificial insemination was carried out using freshly diluted semen ( 0 hour) and semen preserved for 24, 48, 72, 96 and 120 hours in 30, 5, 4, 3, 3 and 2 sows respectively. Animals were inseminated first after 4 hours from the time of exhibition of stance reflex, and a second insemination 12 to 16 hours thereafter. Goldenpig Catheters (IMV Technologies, L'Aigle cedex, France) were used for intra-uterine artificial insemination of the animals with preserved semen. The conception rate was expressed as a percentage.

Statistical analysis. The statistical analyses of data were performed using one way ANOVA with the Statistical Analysis Systems (enterprise Guide 4.2 version), and Duncan's Multiple Range Test was applied to compare the differences between mean values. When ANOVA revealed a significant effect, values were compared by the Least Significant Difference Multiple Comparison Post Hoc Test. Differences were considered significant if the calculated probability of their occurrence by chance was $5 \%(\mathrm{P}<0.05)$.

\section{Results and discussion}

All the freshly collected semen samples (24) were positive for bacterial growth. The mean bacterial load was $25750.00 \pm 7141.14,14933.33 \pm$ $4387.68,9033.33 \pm 1967.51$ and $8341.67 \pm 1732.55$ cfu per $\mathrm{mL}$ of semen, respectively. Analysis of variance revealed that the mean bacterial load in sperm differed significantly $(\mathrm{P}<0.05)$ among the boars. In contrast, the percentage of samples positive for bacterial contamination reported by previous researchers was found to be $31.20 \%$ (ALTHOUSE and LU, 2005), 74.78\% (MARTIN et al., 2010), and 63.00\% (BRESCIANI et al., 2014). 
In the present study, a total of 46 different bacterial isolates were obtained from 24 freshly collected semen samples. Out of these, 9 different bacterial isolates were confirmed, viz. Staphylococcus aureus (24\%), Escherichia coli (22\%), Bacillus spp. (13\%), Citrobacter spp. (9\%), Pseudomonas spp. (9\%), Staphylococcus epidermidis (9\%), Klebsiella spp. (6\%), Streptococcus spp. (6\%) and Proteus spp. (2\%). Similar results were also observed by GACZARZEWICZ et al., (2016); SEPULVEDA et al., (2016) in boar semen.

The antibiotic sensitivity of 46 different bacterial isolates are presented in Table 2, which shows that most of the bacteria were sensitive to Gentamicin $(89 \%)$. The results of the present study are in accordance with the earlier studies by SONE (1990). The differences in the sensitivity of the antibiotic against the micro-organism isolated might be due to the differences in the type of bacteria isolated and/ or due to the development of drug resistance as a result of indiscriminate use of the drugs studied, in treatment or as feed additives.

In the present study, data on the effect of different antimicrobials at different hours of preservation at $15^{\circ} \mathrm{C}$ are presented in Table 3 .

Analysis of variance revealed that the variation in the mean percentage of sperm motility, intact acrosome and HOST-reacted sperm was significant $(\mathrm{P}<0.01)$ between antimicrobial agents and preservation periods. The sperm motility, intact acrosome and HOST-reacted sperm were significantly higher $(\mathrm{P}<0.05)$ in extended semen containing Gentamicin than that containing $\mathrm{KMnO}_{4}$ and Turmeric, at all hours of preservation. However, it was significantly higher $(\mathrm{P}<0.05)$ in the extender containing Turmeric than in $\mathrm{KMnO}_{4}$. Turmeric contains a polyphenolic compound, Curcumin, which is efficacious as an anti-apoptotic, antioxidant and anti-toxic (OMUR and COYAN, 2016). Curcumin may exhibit significant ROS scavenging activities, which may prevent oxidative insult to spermatozoa, and thus enhance the functional activities of spermatozoa (TVRDA et al., 2016). The lowest sperm motility in semen extender containing $\mathrm{KMnO}_{4}$ might be due to the fact that it is a strong oxidizing agent, liberating oxygen which oxidizes protoplasm and $\mathrm{MnO}_{2}$, causing an astringent and irritating effect (HOUSE, 2013).

The higher sperm motility recorded in this study in Modena extender with Gentamicin as the antimicrobial agent, was comparable with the findings of KHAN et al., 2006. However, the values in the present study were higher than the reports by CEROVSKY and VINTER (1986). In contrast, a significant reduction of sperm motility was observed in Gentamicin treated samples by previous researchers (JASKO et al., 1993). The variations in sperm motility containing Gentamicin might be due to variations in preservation temperature, dilution rate, the $\mathrm{pH}$ of the extender, the breed and age of the boars, and the semen processing procedure.

The mean intact acrosome in Modena extender using Gentamicin as a antimicrobial agent was in accordance with the report by KHAN et al., (2006). The present results were lower than those of TYNGKAN, (2009) in Hampshire boar semen.

Significantly more HOST-reacted spermatozoa were observed in the extender containing Gentamicin. Contrary to the present finding, SAIKIA et al., (2016) reported significantly higher HOST-reacted spermatozoa in extender containing $\mathrm{KMnO}_{4}$. The membrane integrity of the sperm in extender containing curcumin reported by OMUR and COYAN, (2016) was higher than the present findings.

In the present study, the mean bacterial load per $\mathrm{mL}$ of boar semen during preservation in Modena extender containing different antimicrobial agents is presented in Table 4. Analysis of variance revealed that the mean value of bacterial load differed highly significantly $(\mathrm{P}<0.01)$ between antibacterial agents and preservation periods. The mean bacterial load recorded for extended semen containing Gentamicin was significantly lower $(\mathrm{P}<0.05)$ than that containing $\mathrm{KMnO}_{4}$ and Turmeric during preservation at $15{ }^{\circ} \mathrm{C}$. The comparatively better efficiency of Gentamicin observed in the current study against different micro-organisms harboured in semen is in agreement with earlier studies (GACZARZEWIEZ et al., 2016). 


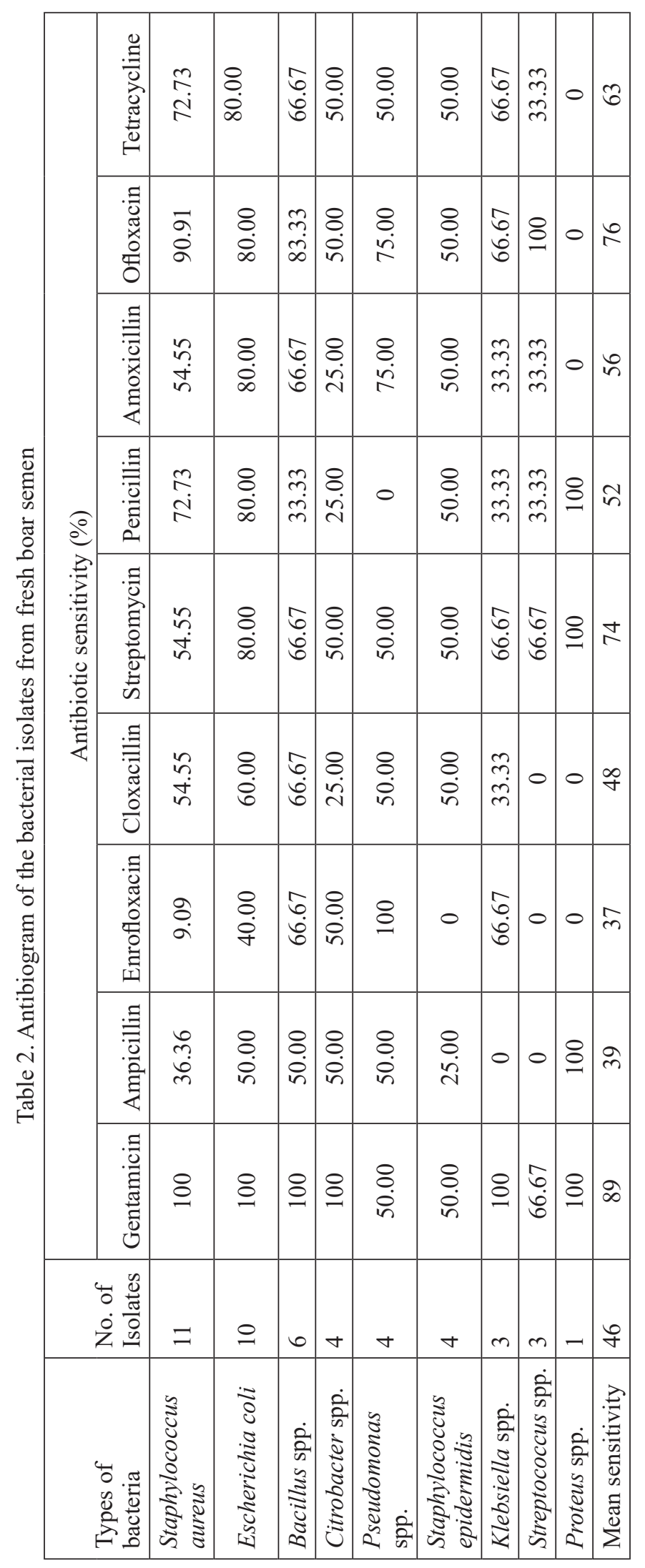

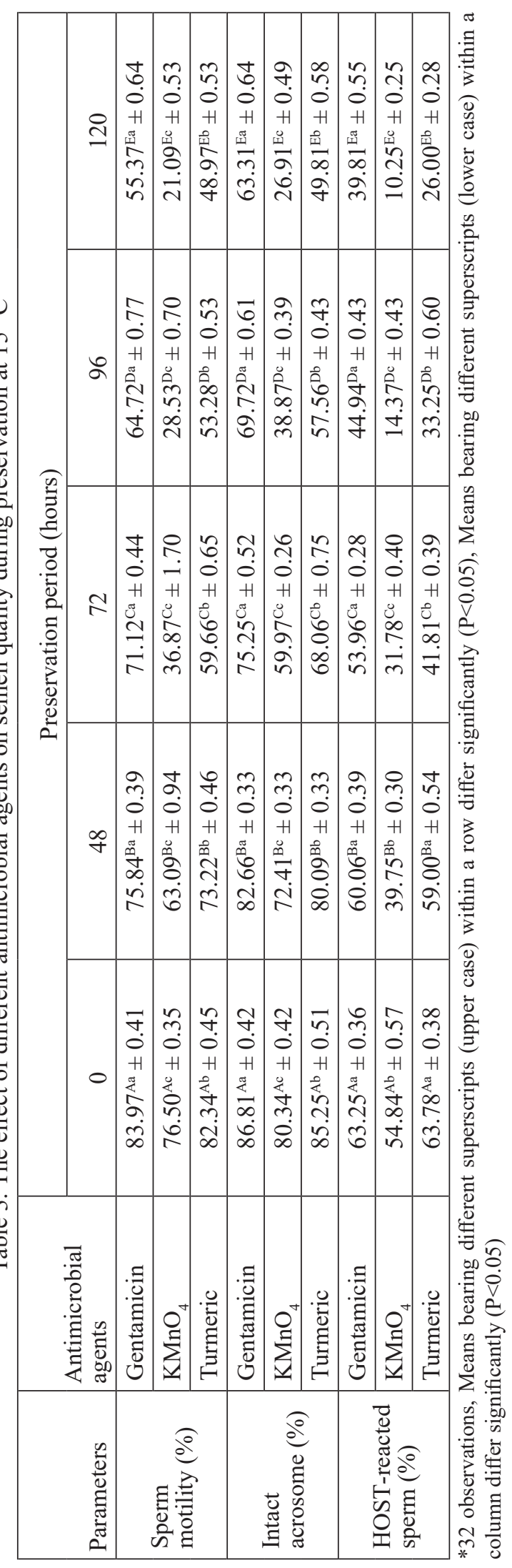


N. K. Manpoong et al.: Efficacy of potassium permanganate and turmeric as antimicrobial agents on the bacterial load and quality of boar semen during preservation

Table 4. Bacterial load (cfu per mL ) in boar semen during preservation at $15{ }^{\circ} \mathrm{C}$ in Modena extender containing different antimicrobial agents

\begin{tabular}{|l|c|c|c|c|c|}
\hline \multirow{3}{*}{$\begin{array}{l}\text { Antimicrobial } \\
\text { agents }\end{array}$} & \multicolumn{5}{|c|}{ Preservation period (hours) } \\
\cline { 2 - 6 } & 0 & 48 & 72 & 96 & 120 \\
\hline \multirow{2}{*}{ Gentamicin } & $265.62^{\mathrm{Aa}}$ & $290.62^{\mathrm{Aa}}$ & $314.06^{\mathrm{Aa}}$ & $350.00^{\mathrm{Aa}}$ & $371.87^{\mathrm{Aa}}$ \\
& \pm 50.72 & \pm 57.39 & \pm 64.73 & \pm 69.56 & \pm 73.81 \\
\hline \multirow{2}{*}{ KMnO4 } & $1090.63^{\mathrm{Ab}}$ & $1265.63^{\mathrm{ABb}}$ & $1415.63^{\mathrm{ABb}}$ & $1481.25^{\mathrm{Bb}}$ & $1553.13^{\mathrm{Bb}}$ \\
& \pm 98.72 & \pm 111.04 & \pm 130.37 & \pm 132.93 & \pm 141.35 \\
\hline \multirow{2}{*}{ Turmeric } & $1289.06^{\mathrm{Ab}}$ & $1762.50^{\mathrm{ABc}}$ & $1996.88^{\mathrm{ABCc}}$ & $2171.88^{\mathrm{BCc}}$ & $2612.50^{\mathrm{Cc}}$ \\
& \pm 159.41 & \pm 237.20 & \pm 280.67 & \pm 304.54 & \pm 372.16 \\
\hline \multirow{2}{*}{ Mean } & $881.77^{\mathrm{A}}$ & $1106.25^{\mathrm{AB}}$ & $1242.19^{\mathrm{BC}}$ & $1334.38^{\mathrm{BC}}$ & $1512.50^{\mathrm{C}}$ \\
& \pm 769.69 & \pm 1062.25 & \pm 1239.36 & \pm 1331.70 & \pm 1599.42 \\
\hline
\end{tabular}

*32 observations, Means bearing different superscripts within a row (upper case) differ significantly ( $\mathrm{P}<0.05)$, Means bearing different superscripts within a column (lower case) differ significantly $(\mathrm{P}<0.05)$

In that study, Gentamicin sulphate employed during semen preservation especially limited the growth of gram negative bacteria, while the growth of gram positive contaminates was not so strongly inhibited, which was in agreement with the present findings. The bacterial load in extender containing $\mathrm{KMnO}_{4}$ was significantly higher $(\mathrm{P}<0.05)$ than with Gentamicin. $\mathrm{KMnO}_{4}$ is a strong oxidizing agent. It liberates oxygen, and atomic oxygen leads to irreversible damage to the bacteria. Due to its strong oxidizing properties, $\mathrm{KMnO}_{4}$ is disinfectant, anti-infective and bactericidal but it is only effective in higher concentrations (HOUSE, 2013). In the current study, the growth of bacteria in semen during preservation might be due to the low concentration of $\mathrm{KMnO}_{4}(10 \mu \mathrm{M})$ in the extender. The mean bacterial load was highest in extender containing Turmeric at the concentration of $0.5 \mathrm{mM}$. MOGHADAMTOUSI et al., (2014) demonstrated that the Minimum Inhibitory Concentration (MIC) value of curcumin was 4 to $16 \mathrm{~g} / \mathrm{L}$ and the Minimum Bactericidal Concentration (MBC) value was 16 to $32 \mathrm{~g} / \mathrm{L}$. TEOW et al. (2016) opined that curcumin exerted a more potent antibacterial effect when used in combination with various other antimicrobial agents. A sub-inhibitory dose of curcumin without any combination with any antibiotic might be the reason for high bacterial growth during preservation of boar semen. The differences in the bacterial count of neat boar semen might be due to the method of semen sampling, the degree of contamination in the preputial diverticulum, and different management practices (DUBIEL et al., 1981; KHER and DHOLAKIA, 1984).

A total of three preserved semen samples, containing Gentamicin, $\mathrm{KMnO}_{4}$ and Turmeric, respectively, were tested for bacterial isolation. In this study, Staphylococcus spp. and Pseudomonas spp. were isolated in semen samples containing Gentamicin. However, Staphylococcus spp., Pseudomonas spp. and Escherichia coli were isolated in semen samples containing $\mathrm{KMnO}_{4}$ and Turmeric, respectively, during preservation at 15 ${ }^{\circ} \mathrm{C}$. The present findings are in accordance with the report by BRESCIANI et al., 2014. The antibiogram of these isolates revealed resistance to Gentamicin, as also reported by BRESCIANI et al., 2014.

A total of 47 oestrus pigs were inseminated with the semen extended in Modena extender containing Gentamicin, and the subsequent farrowing rate for the semen preserved for $0,24,48,72,96$ and 120 hours of preservation was $83.33,80.00,75.00$, $66.66,66.66$ and $50.00 \%$ respectively. In contrast, variable conception rates were reported by previous researchers (FITZGERALD et al., 2008). In the present study, the preserved semen with ascending bacterial load containing Gentamicin did not affect the conception rate. Similarly, ALTHOUSE et al., (2008) estimated that the amount of bacteria necessary to produce a detrimental effect on a standard seminal dose containing $3 \times 10^{9}$ sperm was $3 \times 10^{7}$ to $3 \times 10^{9}$. 


\section{Conclusion}

In conclusion, this study showed that the quality of boar semen, assessed on the basis of sperm motility, intact acrosome and HOSTreacted sperm, was significantly higher in extended semen containing Gentamicin than extended semen containing $\mathrm{KMnO}_{4}$ and Turmeric during preservation at $15^{\circ} \mathrm{C}$. $\mathrm{KMnO}_{4}$ and Turmeric were significantly less effective in control of bacterial load during preservation compared to Gentamicin. Bacterial contamination in semen can be minimized by adopting strict hygienic practices, even without adding antimicrobial agents during processing, but adding antimicrobial agents to semen extender to control semen contamination is unavoidable. The best results can be obtained by studying the antibiogram of bacterial isolates from the semen, then changing the antimicrobial agents and their dose for incorporation during semen processing. We suggest further investigations regarding semen quality using different natural antimicrobial agents that hold the possibility of substituting conventional antibiotics for use in semen extenders.

\section{Acknowledgements}

All the authors are thankful to the Director of Research (Veterinary), Assam Agricultural University for his kind helps.

\section{References}

Althouse, G. C., C. E. KUSter, S. G. ClARK, R. M. WEISIGER (2000): Field investigations of bacterial contaminants and their effects on extended porcine semen. Theriogenology 53, 1167-1176.

DOI: $10.1016 / \mathrm{S} 0093-691 \mathrm{X}(00) 00261-2$

AlThOUSE, G. C., K. G. LU (2005): Bacteriospermia in extended porcine semen. Theriogenology 63, 573-584.

DOI: 10.1016/j.theriogenology.2004.09.031

Althouse, G. C., M. S. PIERDON, K. G. LU (2008): Thermotemporal dynamics of contaminant bacteria and antimicrobials in extended porcine semen. Theriogenology 70, 1317-1323.

DOI: $10.1016 /$ j.theriogenology.2008.07.010

BLOM, E. (1950): A simple rapid staining method for the differentiation between live and dead sperm cells by means of Eosin and Nigrosin. Nord. Vet. Med. 2, 58.

BRESCIANI, C., C. S. CABASSI, G. MORINI, S. TADDEI, R. BETTINI, E. BIGLIARDI, F. D. LANNI, A. SABBIONI, E. PARMIGIANI (2014): Boar semen bacterial contamination in Italy and antibiotic efficacy in a modified extender. Ital. J. Anim. Sci. 13, 83-87.

DOI: $10.4081 /$ ijas.2014.3082

BUCHANAN, R. E., N. E. GIBBONS (1974): Bergey's manual of determinative bacteriology. $8^{\text {th }}$ ed., The Williams and Wilkins Company, Baltimore.

CEROVSKY, J., P. VINTER (1986): The effect of a synthetic analogue of $\mathrm{PGF}_{2 \alpha}$-oestrogen spofa- on boar spermatozoa in diluted semen stored for a short period. Zivocisna Vyroba, 30, 237-244.

CRUICKSHANK, R., J. P. DUGUID, B. P. MARMION, R. H. A. SWAIN (1975): Medical Microbiology. $12^{\text {th }}$ ed., Churchill Livingtone, Edinburgh, London and New York.

DUBIEL, A., J. F. STANCZYK, J. KROLINSKI, T. FRONCZEK, K. FURMANSKI, J. CISZEWSKI (1981): Bacterial flora in ejaculates of boars. Medycyna Wet. 37, 486-488.

FITZGERALD, R. F., G. F. JONES, K, J. STALDER (2008): Effect of intrauterine and cervical artificial-insemination catheters on farrowing rate and litter size. J. Swine Health Prod. 16, 10-15.

FRACZEK, M., M. HRYHOROWICZ, D. GACZARZEWICZ, A. SZUMALA-KAKOL, T. J. KOLANOWSKI, L. BEUTIN (2015): Can apoptosis and necrosis coexist in ejaculated human spermatozoa during in vitro semen bacterial infection? J. Assist. Reprod. Genet. 32, 771-779.

DOI: $10.1007 / \mathrm{s} 10815-015-0462-\mathrm{x}$

FRACZEK, M., M. KURPISZ (2015): Mechanisms of the harmful effects of bacterial semen infection on ejaculated human spermatozoa: potential inflammatory markers in semen. Folia Histochem. Cytobiol. 53, 201-217.

DOI: $10.5603 /$ fhc.a2015.0019

FRACZEK, M., M. PIASECKA, D. GACZARZEWICZ, A. SZUMALA-KAKOL, A. KAZIENKO, S. LENART (2012) Membrane stability and mitochondrial activity of human ejaculated spermatozoa during in vitro experimental infection with Escherichia coli, Staphylococcus haemolyticus and Bacteriodes ureolyticus. Andrologia 44, 315-329.

DOI: $10.1111 / \mathrm{j} .1439-0272.2012 .01283 . \mathrm{x}$

GACZARZEWICZ, D., J. UDALA, M. PIASECKA, B. BLASZCZYK, T. STANKIEWICZ (2016): Bacterial contamination of boar semen and its relationship to sperm quality preserved in commercial extender containing gentamicin sulfate. Pol. J. Vet. Sci. 19, 451-459.

DOI: $10.1515 /$ pjvs-2016-0057

HOUSE, J. E. (2013): Inorganic Chemistry. $2^{\text {nd }}$ ed., Academic Press, 223 Wyman Street, Waltham, MAO2451, USA.

JASKO, D. J., S. J. BEDFORD, N. L. COOK, E. L. MUMFORD, E. L. SQUIRES, E. W. PICKET (1993): Effect of antibiotics on motion characteristics of cooled Stallion spermatozoa. Theriogenology 40, 885-893.

DOI: 10.1016/0093-691X(93)90356-A 
N. K. Manpoong et al.: Efficacy of potassium permanganate and turmeric as antimicrobial agents on the bacterial load and quality of boar semen during preservation

KHER, H. N., P. M. DHOLAKIA (1984): Bacteriological studies of bovine semen. Indian J. Anim. Reprod. 5, 78-84.

KOHN, F. M., I. ERDMANN, T. OEDA, K. F. EL-MULLA, H. G. SCHIEFER, W. B. SCHILL (1998): Influence of urogenital infections on sperm function. Andrologia 30, 73-80.

DOI: 10.1111/j.1439-0272.1998.tb02829.x

KHAN, M. H., S. NASKAR, A. DAS, R. K. BORDOLOI (2006): Comparative efficacy of different diluents on liquid preservation of boar semen. Indian J. Anim. Sci. 76, 780-783.

MARTIN, L. O. M., E. C. MUNOZ, F. D. CUPERE, E. V. DRIESSCHE, D. E. BLANCO, J. M. RODRIGUEZ, S. BEECKMANS (2010): Bacterial contamination of boar semen affects the litter size. Anim. Reprod. Sci. 120, 95-104. DOI: 10.1016/j.anireprosci.2010.03.008

MOGHADAMTOUSI, S. Z., H. A. KADIR, P. HASSANDARVISH, H. TAJI, S. ABUBAKAR, K. ZANDI (2014): A review on antibacterial, antiviral and antifungal activity of curcumin. BioMed Res. International, 2014, 1-12.

DOI: $10.1155 / 2014 / 186864$

MORRELL, J. M., M. WALLGREN (2011): Removal of bacteria from ejaculates by single layer centrifugation and reduce the use of antibiotics in semen extender. Anim. Reprod. Sci. 123, 64-69.

DOI: 10.1016/j.anireprosci.2010.11.005

OMUR, A. D., K. COYAN (2016): Protective effects of the antioxidants curcumin, ellagic acid and methionine on motility, mitochondrial transmembrane potential, plasma membrane and acrosome integrity in freeze-thawed Merino ram perm. Veterinarni Medicina, 61, 10-16.

DOI: 10.17221/8677-VETMED

PRIETO-MARTINEZ, N., E. BUSSALLEU, E. GRACIABONAVILA, S. BONET, M. YESTE (2014): Effects of Enterobacter cloacae on boar sperm quality during liquid storage at $17^{\circ} \mathrm{C}$. Anim. Reprod. Sci. 148, 72-82.

DOI: 10.1016/j.anireprosci.2014.05.008

REVELL, S. G., R. A. MRODE (1994): An osmotic resistance test for bovine semen. Anim. Reprod. Sci. 36, 77-86.

DOI: 10.1016/0378-4320(94)90055-8

SAIKIA, T., K. AHMED, P. M. BARUA, B. C. DEKA, N. AHMED (2016): Effect of certain additives on quality of boar semen during preservation at $15{ }^{\circ} \mathrm{C}$ and $5{ }^{\circ} \mathrm{C}$. Theriogenology Insight 6, 45-51.

DOI: $10.5958 / 2277-3371.2016 .00006 .1$
SEPULVEDA, L., E. BUSSALLEU, M. YESTE, S. BONET (2016): Effect of Pseudomonas aeruginosa on sperm capacitation and protein phosphorylation of boar spermatozoa. Theriogenology 85, 1421-1431.

DOI: 10.1016/j.theriogenology.2015.12.025

SHIPLEY, C. F. (1999): Breeding soundness examination of the boar. Swine Health Prod. 7, 117-120.

SONE, M. (1990): Investigations on the control of bacteria in boar semen. Japanese J. Anim. Reprod. 36, 23-29.

SONE, M., M. CHIKYU, M. YOSHIDA, K. BAMBA, A. OGASA (1992): Prolonged storage of boar semen in liquid form. Japanese J. Swine Sci. 29, 41-50.

DOI: 10.5938 /youton.29.41

TEOW, S. Y., K. LIEW, S. A. ALI, A. S. B. KHOO, S. C. PEH (2016): Antibacterial action of curcumin against Stahylococcus aureus: A brief review. J. Trop. Med. 2016, 2853045.

DOI: $10.1155 / 2016 / 2853045$

TYNGKAN, L. (2009): Effect on holding time, removal of seminal plasma and extender on quality of boar semen during preservation at $18{ }^{\circ} \mathrm{C}$. M.V.Sc. Thesis, Assam Agricultural University, Guwahati, India.

TVRDA, E., M. HALENAR, H. GREIFOVA, A. MACKOVICH, F. HASHIM, N. LUKAC (2016): The effect of curcumin on cryopreserved bovine semen. Int. J. Anim. Vet. Sci. 10, 707-711.

DOI: 10.5281 /zenodo. 1127328

UBEDA, J. L., R. AUSEJO, Y. DAHMANI, M. V. FALCETO, A. USAN, C. MALO (2013): Adverse effects of members of the Enterobacteriacee family on boar semen quality. Theriogenology 80, 565-570.

DOI: 10.1016/j.theriogenology.2013.05.022

YANIZ, J. L., M. A. MACRO-AGUADO, J. A. MATEOS, P. SANTOLARIA (2010): Bacterial contamination of ram semen, antibiotic sensitivities, and effects on sperm quality during storage at $15{ }^{\circ} \mathrm{C}$. Anim. Reprod. Sci. 122, 142-149. DOI: 10.1016/j.anireprosci.2010.08.006

ZEMJANIS, R. (1970): Collection and evaluation of semen. Diagnostic and therapeutic techniques in animal reproduction. $2^{\text {nd }}$ ed., Williams and Wilkins Co., Baltimore.

Received: 16 May 2019

Accepted: 24 September 2019 
MANPOONG, N. K., K. AHMED, D. K. BHATTACHARYA, D. K. SARMA, N. AHMED, A. DAS: Učinkovitost kalijeva permanganata i kurkume kao antimikrobnih tvari na broj bakterija i kvalitetu nerastovog sjemena pohranjenog na $15^{\circ} \mathrm{C}$. Vet. arhiv 90, 443-451, 2020.

\section{SAŽETAK}

Istraživanje je provedeno kako bi se procijenila učinkovitost različitih prirodnih antimikrobnih tvari (KMnO4 i kurkume) u odnosu na konvencionalne antibiotike na broj bakterija i kvalitetu nerastova sjemena, pohranjenog u ekstenderu Modena do 120 sati na $15^{\circ} \mathrm{C}$. Upotrijebljeno je ukupno 56 ejakulata, 14 od svakoga od četiri nerasta križane pasmine Hampshire, uzgajanih u centru za istraživanje svinja ICAR-AICRP, Guwahati, Assam, Indija. Trideset i dva ejakulata, po 8 od svakoga od 4 nerasta, upotrijebljena su kako bi se istražili učinci antimikrobnih tvari na kvalitetu sjemena za vrijeme njegove pohrane u ekstenderu Modena na $15^{\circ} \mathrm{C}$. Identificirano je ukupno 9 različitih bakterijskih tipova iz 46 bakterijskih izolata dobivenih od 24 uzorka svježeg sjemena, i to Staphylococcus aureus (24 \%), E. coli (22 \%), Bacillus spp. (13\%), Citrobacter spp. (9\%), Pseudomonas spp. (9\%), Staphylococcus epidermidis (9\%), Klebsiella spp. (6\%), Streptococcus spp. (6\%) i Proteus spp. (2\%). Ukupna osjetljivost dobivenih izolata bila je: $89 \%$ na gentamicin, $39 \%$ na ampicilin, $37 \%$ na enrofloksacin, $48 \%$ na kloksacilin, $74 \%$ na streptomicin, $52 \%$ na penicilin, $56 \%$ na amoksicilin, $76 \%$ na ofloksacin i $63 \%$ tetraciklin. Prosječna pokretljivost spermija, intaktni akrosomi, reaktivnost sjemena na hipoosmotski test bubrenja (HOST) i broj bakterija znakovito su se razlikovali (P $<0,01)$ među antimikrobnim tvarima (gentamicin, $\mathrm{KMnO}_{4} \mathrm{i}$ kurkuma) i s obzirom na trajanje pohrane $(0,48,72,96$ i 120 sata). Tijekom pohrane na $15^{\circ} \mathrm{C}$, najbolja je bila kvaliteta sperme tretirane gentamicinom a zatim ona tretirana kurkukom i $\mathrm{KMnO}_{4}$. Postotak koncepcije bio je $83,33 \%$ za sjeme koje nije bilo pohranjeno, $80,00 \%$ za sjeme pohranjeno 24 sata, $75,00 \%$ za sjeme pohranjeno 48 sati, $66,66 \%$ za sjeme pohranjeno 72 sata, $66,66 \%$ za sjeme pohranjeno 96 sati i 50,00 \% za sjeme pohranjeno 120 sati. U ovom istraživanju porast broja bakterija u pohranjenom sjemenu tretiranom gentamicinom nije utjecao na postotak koncepcije.

Ključne riječi: antimikrobne tvari; broj bakterija; kvaliteta sjemena; pohrana; koncepcija 
